\title{
A calculated determination and experimental refinement of the optimal value of the single-phase induction motor transformation ratio
}

\author{
Oleksiy Iegorov ${ }^{1}$, \\ Olga Iegorova ${ }^{2}$, \\ Oleksandr Miroshnyk2, \\ Artem Cherniuk $^{3}$ \\ ${ }^{1}$ O. M. Beketov National University \\ of Urban Economy in Kharkiv, \\ 17, Marshal Bazhanov St., \\ 61002, Kharkiv, Ukraine \\ Email:diaskk67@gmail.com \\ ${ }^{2}$ Kharkiv Petro Vasylenko \\ National Technical University of Agriculture, \\ 44, Alchevskih St., \\ 61052, Kharkiv, Ukraine
${ }^{3}$ Ukrainian Engineering Pedagogics Academy, 16, Universitetska St., 61003,
Kharkiv, Ukraine

Induction motors consume almost $70 \%$ of the world's electricity as they are the driving force behind the vast majority of rotary mechanisms [1]. For industrial and domestic purposes alone, about a million new electric motors are commissioned annually. Single-phase induction motors (SPIMs) are superior to all other types of electrical machines that operate on a single-phase AC voltage network because of their simple and robust design and low cost. Therefore, a small improvement in the SPIM energy performance can have a strong impact on energy consumption worldwide and ultimately reduce emissions of harmful substances into environment. This article presents a technique for optimizing SPIM windings in order to maximize efficiency with a given and fixed phase-shifting capacitor. The positive effect of the application of the proposed method is confirmed by the results of SPIM industrial tests with various powers and rotor speeds.

Keywords: Induction motor, windings, phase-shifting capacitor, efficiency, positive and reverse sequence currents

\section{INTRODUCTION}

Single-phase induction electric motors (SPIM) are widely used in various fields of the life of modern society as an electric drive part for the various kinds of devices powered by a single-phase AC network. First of all, SPIMs have become widespread due to their use in household appliances (refrigeration units, water pumps, woodworking machines, medical equipment), which are con- stantly evolving, acquiring new functionality, and intensively penetrating residential and office premises in industrialized countries. Electric motors of this class belong to mass-manufactured motors and are produced in tens of millions units per year [2], which determines the manufacturers' increased interest in improving SPIM design and production technology. At the same time, in line with the last decade's main global trends in the development of electric motors, there is 
a steady preference for improving the energy efficiency of electric drives over the cost of active materials and cost of SPIM production.

The main problem that must be solved when designing SPIMs is obtaining the minimum value of the reverse rotating magnetic field, which is always present in this type of motors. The magnitude of this field depends on the parameters of SPIM design, namely on the value of the phase-shifting capacitor $(C)$ and the transformation ratio $(K)$, which is determined by the ratio of the number of the auxiliary winding effective turns (into which the phase-shifting capacitor is included) to the number of effective turns of the main winding (Fig. 1).

Bibik [3] considers the determining question of optimal capacity of the working capacitor with a previously known and fixed coefficient $K$. In practice, when developing SPIM, the task is to determine the winding data with a previously known standard capacity of the working capacitor. The industry produces the capacitors with certain discrete capacitance values: $6,8,12,16$, and $20 \mu \mathrm{F}$. To obtain a motor field close enough to a circular field, choosing a strictly defined capacitance in advance, it is necessary to vary the auxiliary parameters, i.e. the transformation ratio $K$ value.

Analyzing scientific articles on design issues of the SPIM, one can come to the conclusion that this problem has not been previously studied. So, Ghial et al. [4] considered the method of obtaining optimal parameters of the SPIM with varying phase-shifting capacitor capacitance value is, but do not take into account the discreteness of the series of capacitor values. In [5], the transformation ratio has been replaced by a calculated complex voltage ratio based on the assumption that a single-phase motor for parameter conversion can be represented as an ideal transformer. This approach idealizes the SPIM and does not take into account the peculiarities of the used winding conductors. Finkelshtein et al. [6] propose a method for calculating the operating and SPIM energy characteristics based on the solving electromagnetic equations results. Parameters of the phase-shifting capacitor and the SPIM transformation ratio, at which a circular magnetic field exists in the air gap, have been determined. But in practice, obtaining an ideal circular magnetic field is impossible and it is this factor that must be taken into account by the designer when solving the problem of the optimization of SPIM design. Undoubtedly, the aforementioned scientific works make a great contribution to the solution of the issues in SPIM design, but they do not offer a methodology that would take into account the limitations that a developer faces in practice in the conditions of industrial mass production. Sharma et al. [7] investigated the effect of single-phase alternating current on the performance of an alternating current motor, but they did not take into account the value of the transformation ratio per value of the reverse sequence current. Iegorov et al. [8], describe a method for determining such parameters for the capacitor and auxiliary winding, in which there is no reverse circular rotating field and only a direct circular rotating field acts in the SPIM gap. However, these authors did not take into account the fact that there is only one combination for capacitance $X_{c}$ and the transformation coefficient between the auxiliary and main windings $K$, which provides a circular rotating field in the SPIM. Also, they propose increasing

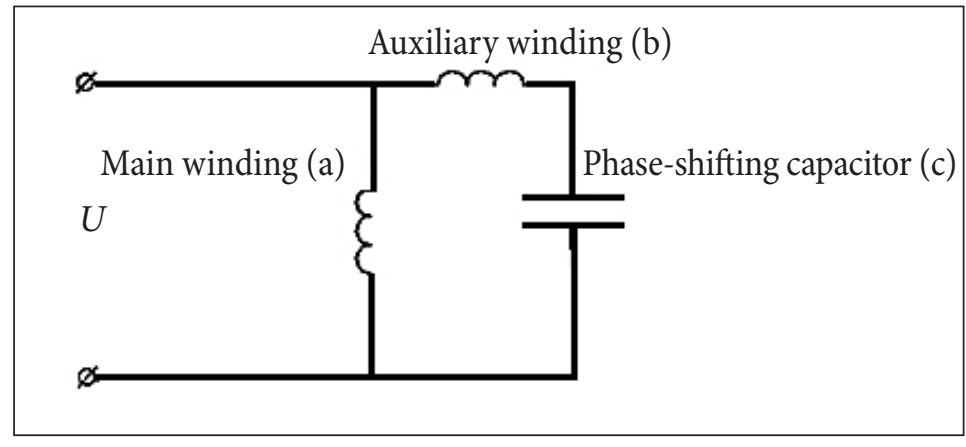

Fig. 1. Diagram of the winding connection of SPIM 
the axial length of stator and rotor packets to reduce the total losses and increase the SPIM efficiency. But this increases the cost of the SPIM and worsens its overall dimensions.

The aim of research is to determine the optimal (that is, having the minimum value for the stator reverse field) auxiliary SPIM winding parameters, subject to a given phase-shifting capacitance value and designed according to the proposed method of the main stator winding [9].

\section{METHODOLOGY}

The indicator of the ellipticity degree of the magnetic field of the SPIM is the negative sequence current magnitude [10]:

$$
I_{a 2}=\frac{U \cdot\left(Z_{b 1}+j K \cdot Z_{a 1}\right)}{Z_{a 1} \cdot Z_{b 2}+Z_{a 2} \cdot Z_{b 1}}
$$

where $Z_{a 1}, Z_{a 2}$ - the direct and reverse sequences complex resistances for the main winding; $Z_{b 1}$, $Z_{b 2}$ - the direct and reverse sequences complex resistances for the auxiliary winding; $U$ - supply voltage; $K$ - the transformation ratio.

It is known that the SPIM field will be circular when the reverse sequence current is zero [11]. This will be done provided:

$$
Z_{b l}+j K \cdot Z_{a l}=0
$$

Expanding expression (2) through the active and inductive components of the resistances for the forward and reverse sequences and replacing the parameters for the auxiliary winding " $b$ " using the transformation ratio " $K$ " to the main winding " $a$ " parameters, we obtain the system of equations:

$$
\begin{aligned}
& K^{2} \cdot R_{a 1}-K \cdot X_{a 1}=0 \\
& K^{2} \cdot X_{a 1}-X_{c}+K \cdot R_{a 1}=0
\end{aligned}
$$

where $R_{a 1}, R_{a 2}, X_{a 1}, X_{a 2}$ - the active and inductive resistances the main phase forward and reverse sequences, Ohm; $X_{c}$ - the phase-shifting capacitance inductive resistance, $\mathrm{Ohm}$.

Examining the equation system (3) to find an extreme, we make sure that the SPIM magnetic field will be circular only for the one pair of $K$ and $X_{c}$ values, i.e. when:

$$
\begin{aligned}
& K=\frac{X_{a 1}}{R_{a 1}} \\
& X_{c}=X_{a 1} \cdot\left(1+K^{2}\right) .
\end{aligned}
$$

In practice, the standard capacitor capacity may not correspond to the optimal resistance $X_{c}$ from expression (4). Therefore, it is necessary to solve the searching problem for $K$ with a known $X_{c}$ in advance, at which the magnetic field of the SPIM will be as close to circular as possible.

Consider the reverse sequence current module (1). Differentiate this expression with respect to the variable $K$ and obtain expression (5):

$$
\begin{aligned}
& \left(I_{a 2}\right)^{\prime}=U \frac{Q \cdot\left(A^{2}+B^{2}\right)-4 K \cdot P \cdot}{P^{4}-A \cdot B \cdot\left(1+K^{2}\right)+Q \cdot\left(1+K^{4}\right) \cdot X_{c}} \\
& \frac{\left(A \cdot\left(R_{a 1} \cdot R_{a 2}-X_{a 1} \cdot X_{a 2}\right)+B \cdot\left(R_{a 1} \cdot X_{a 2}+R_{a 2} \cdot X_{a 1}\right)\right)}{P^{4}-A \cdot B \cdot\left(1+K^{2}\right)+Q \cdot\left(1+K^{4}\right) \cdot X_{c}},
\end{aligned}
$$

where

$$
\begin{aligned}
& A=2 K^{2} \cdot\left(R_{a 1} \cdot R_{a 2}-X_{a 1} \cdot X_{a 2}\right)+X_{c} \cdot\left(X_{a 1}+X_{a 2}\right) ; \\
& B=2 K^{2} \cdot\left(R_{a 1} \cdot X_{a 2}+X_{a 1} \cdot R_{a 2}\right)-X_{c} \cdot\left(R_{a 1}+R_{a 2}\right) ; \\
& Q=2 K^{3} \cdot\left(R_{a 1}^{2}+X_{a 1}{ }^{2}\right)+ \\
& K \cdot\left(R_{a 1}{ }^{2}+X_{a 1}{ }^{2}-2 X_{a 1} \cdot X_{c}\right)-X_{c} \cdot R_{a 1} ; \\
& P=\left(K^{4}+K^{2}\right) \cdot\left(R_{a 1}{ }^{2}+X_{a 1}{ }^{2}\right)- \\
& 2 K \cdot X_{c} \cdot\left(R_{a 1}+X_{a 1}\right)+X_{c}^{2} .
\end{aligned}
$$

In order to determine the minimum points, i.e., the extreme of the function $I_{a 2}=f(K)$, it is necessary to equate the found expression $\left(I_{a 2}\right)$ ' for the derivative to zero and solve the equation for $K$. Obviously, expression (5) becomes zero if the numerator is equal to zero. We determined the $K$ value by the iterative method, at which the negative sequence current derivative turns to zero. We checked the condition that the given point for the function $I_{a 2}=f(K)$ was a local minimum point: if the derivative from minus infinity to equation $K$ solution point is negative, and from the obtained point $K$ to infinity it is positive, then 
the found solution $K$ is the minimum point. In the physical sense, at this value for the transformation ratio $K$, the reverse sequence current $I_{a 2}$ value has a minimum value, i.e. the field in the SPIM air gap is as close to circular as possible.

In practice, it is necessary to solve the problem of clarifying the optimal transformation ratio $K$ when testing SPIM prototypes. In order to determine the optimal value for $K$ by calculation, it is necessary to know the impedances for the main and auxiliary phases of the direct and reverse sequences, which is usually a significant difficulty, since the exact rotor slip $(s)$ value at rated power is not known at the SPIM design stage.

The authors propose a method for determining the optimal value of the transformation ratio $K$, which can be conditionally divided into two stages:

1. The coefficient $K$ is preliminarily calculated according to the method discussed above and the auxiliary winding effective conductor number is determined.

2. After the prototype production, an experimental refinement for the $K$ coefficient is made.

A SPIM with a field shape in the air gap close to circular will retain its circular shape when the winding parameters change, if the following resistance ratio is maintained:

$$
\frac{K^{2}\left(R_{a}^{2}-X_{a}^{2}\right)}{X_{c} \times\left(X_{a}-R_{a}\right)+2 X_{a} R_{a} K^{2}}=\text { const }
$$

where $R_{a}, X_{a}$ - active and inductive components for the main phase, respectively, Ohm.

During the prototype tests, such value selection for the phase-shifting capacitor capacitance $\left(\mathrm{C}_{\text {opt }}\right)$ is made, at which SPIM efficiency and power factor have the highest values. In this case, the SPIM field has the form closest to the circular field, and the negative sequence current is minimal. However, the experimentally determined optimal capacity $\left(\mathrm{C}_{\text {opt }}\right)$ differs from the standard capacity value that is available to the manufacturer.

It is necessary to change the number of the auxiliary winding effective turn in this way, i.e. the coefficient $K$, so that when using a standard electrical capacity, the field shape is as close to circular as possible.
Let us write down the relation (6) for a circular field for two cases: when the optimal coefficient $K$ is known and when the optimal capacity $\mathrm{C}_{\text {opt }}$ is determined, i.e. $\mathrm{Xc}_{\text {opt }}$ :

$$
\begin{gathered}
\frac{K_{o p t}^{2}\left(R_{a}^{2}-X_{a}^{2}\right)}{X_{c} \times\left(X_{a}-R_{a}\right)+2 X_{a} R_{a} K_{o p t}^{2}} \\
=\frac{K^{2}\left(R_{a}^{2}-X_{a}^{2}\right)}{X c_{o p t}\left(X_{a}-R_{a}\right)+2 X_{a} R_{a} K^{2}} .
\end{gathered}
$$

We multiply the numerator and denominator for the right side of (7) by the ratio $X_{c} / X_{o p t}$ :

$$
\begin{gathered}
\frac{K_{o p t}^{2}\left(R_{a}^{2}-X_{a}^{2}\right)}{X_{c} \times\left(X_{a}-R_{a}\right)+2 X_{a} R_{a} K_{o p t}^{2}} \\
=\frac{K^{2}\left(R_{a}^{2}-X_{a}^{2}\right) \frac{X c}{X c_{o p t}}}{X_{c} \times\left(X_{a}-R_{a}\right)+2 X_{a} R_{a} K^{2} \frac{X c}{X c_{o p t}}} .
\end{gathered}
$$

By transforming (8), it is possible to obtain the optimal coefficient $\mathrm{C}_{\text {opt }}$ value, expressed through the optimal and standard phase-shifting capacitor resistances $X / X c_{o p t}$ :

$$
K_{\text {opt }}=\sqrt{\frac{X c}{X c_{o p t}}} .
$$

This technique allows determining the optimal transformation ratio $K_{\text {opt }}$ value, which corresponds to the maximum values of SPIM efficiency and power factor without making new SPIM prototypes, i.e. without rewinding the auxiliary winding.

The considered technique was used in designing the AI1E series single-phase induction motors with a $80 \mathrm{~mm}$-high rotation axis at Ukrelectromash JSC (Kharkiv, Ukraine). When developing this series, the main and auxiliary winding SPIM parameters were preliminary calculated according to the method described above [9]. After the prototype production, an experimental determination of the optimal value of the working capacitor capacitance $\left(C_{o p t}\right)$ was carried out, at which the efficiency and power factor were the highest and the consumed SPIM current was the lowest. This corresponded to a magnetic field in the air gap as close to a circular shape as 
possible. After recalculating the winding data to a standard capacitance on $32 \mu \mathrm{F}$, i.e. determination the optimal transformation ratio $C_{o p t}$ according to (9), changes were made in the number of auxiliary winding turns to comply with (9), and then the best motors for this AI1E series were made.

The Table shows the design results for two electric motors from the AI1E series.

Computational studies, which were carried out with the simulation of the magnetic field by the finite element method, showed that the efficiency, direct and reverse sequence currents were dependent on the value of the transformation ratio $(K)$. The main and auxiliary winding values were changed at the fixed value of the phase-shifting capacitor and the results presented in Fig. 2 were obtained.

Due to the discreteness of the number of main and auxiliary winding turns, it is impossible to achieve an absolute circular magnetic field, which corresponds to the calculated optimal transformation ratio $K_{\text {opt }}$. Therefore, in

Table. The AI1E series SPIM design results

\begin{tabular}{|c|c|c|c|c|c|c|}
\hline $\begin{array}{l}\text { Standard } \\
\text { size } \\
\text { motors }\end{array}$ & Development stage & $\begin{array}{c}\text { Coefficient } \\
\text { transformation } K\end{array}$ & $\begin{array}{l}\text { The phase-shifting } \\
\text { capacitor } \\
\text { capacitance } C, \mu \mathrm{F}\end{array}$ & Efficiency, \% & $\begin{array}{l}\text { Common } \\
\text { current, A }\end{array}$ & $\operatorname{Cos}(\varphi)$ \\
\hline \multirow{3}{*}{ Al1E80B2 } & Calculated determination $K$ & 1.47 & 32 & 78.61 & 10.0 & 0.97 \\
\hline & Experimental definition $C_{o p t}$ & 1.47 & 36 & 80.12 & 8.55 & 0.98 \\
\hline & Final option & 1.55 & 32 & 79.88 & 8.61 & 0.98 \\
\hline \multirow{3}{*}{ Al1E80B4 } & Calculated determination $K$ & 1.32 & 32 & 75.17 & 7.0 & 0.98 \\
\hline & Experimental definition $C_{o p t}$ & 1.32 & 38 & 76.16 & 6.15 & 0.99 \\
\hline & Final option & 1.43 & 32 & 75.45 & 6.37 & 0.99 \\
\hline
\end{tabular}

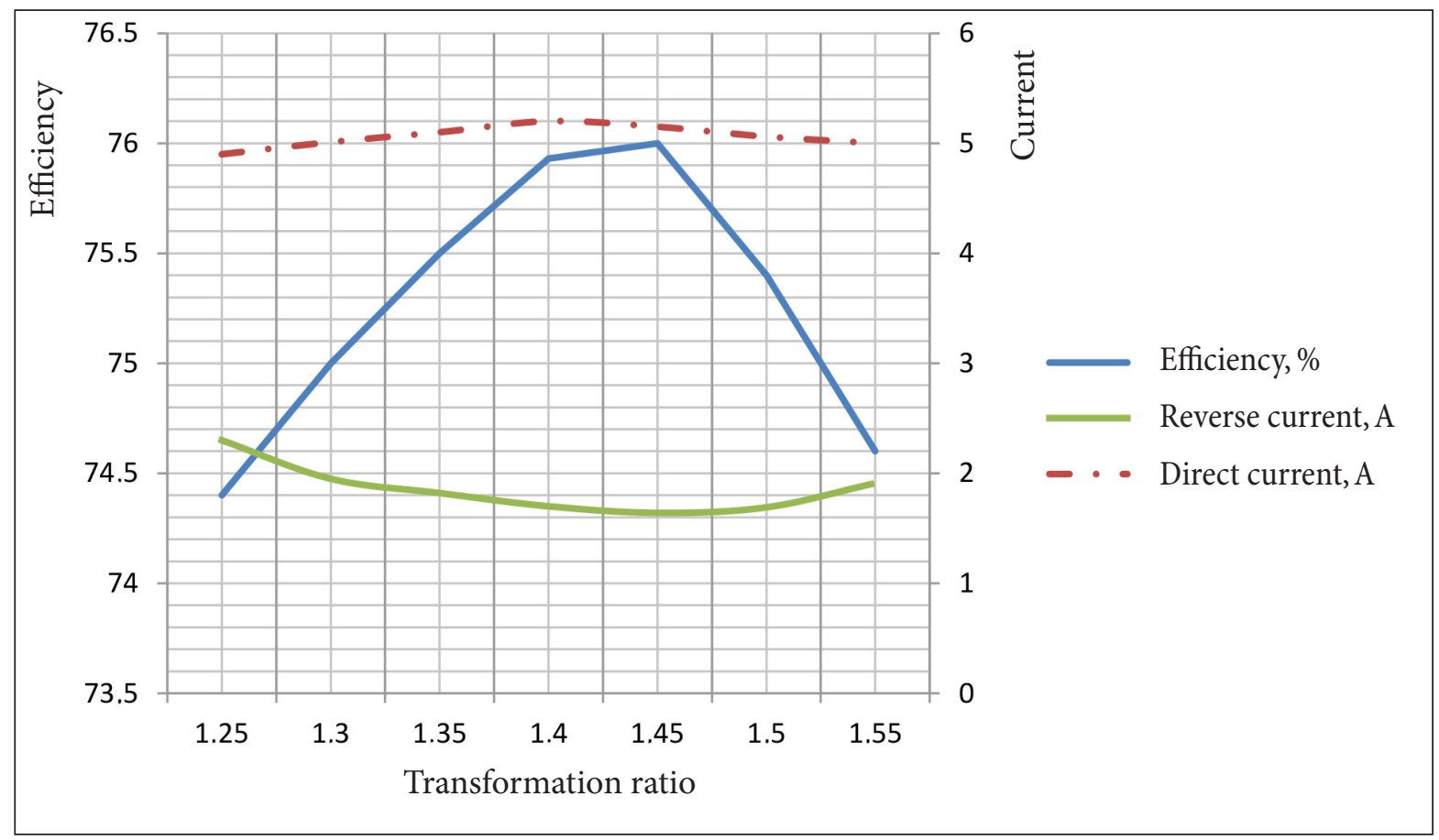

Fig. 2. The efficiency, direct and reverse currents dependence on the transformation ratio 
practice, it is only possible to obtain the field in the shape of an ellipse, but as close as possible to a circular shape.

The theoretical foundations, which are set out in this article, were the basis for the design of the computer calculation program [12], with the help of which electromechanical calculations are currently performed in SPIM design.

\section{CONCLUSIONS}

The proposed method for determining SPIM optimal winding data allows quite accurately, at the electromagnetic calculations stage, to calculate the value for the optimal transformation ratio at a fixed phase-shifting capacitor capacity, which provides an almost circular rotating magnetic field in the magnetic system, the minimum reverse current in the stator winding, and the electric motor maximum efficiency. The technique makes it possible to experimentally clarify the optimal transformation ratio when testing prototypes without changing the SPIM winding parameters, solely by selecting the appropriate value for the phase-shifting capacitor capacitance.

In general, the work confirms the thesis that when designing a SPIM (like any other electric motor), it is necessary to keep in mind the discreteness of the indicators, dimensions, parameters for the elements designed electric motor. Indicators that are discrete in the design of induction motors are the discrete number of poles, the number of stator and rotor slots, the number of slots per pole and phase, the number of conductors in the stator slot, as well as stepwise (discrete) the stator winding conductors resizing and capacitor capacitance values. Because of this discreteness, it is impossible to obtain the perfectly accurate (ideal) circular shape of the SPIM magnetic field in accordance with theoretical mathematical formulas. The proposed method shows a possible way of approaching the actual designing SPIM magnetic field to the ideal circular SPIM magnetic field with minimal ellipticity. As follows from the Table, this SPIM option will be optimal, that is, it will have the maximum efficiency and minimum stator current at the electric motor rated power.

Received 21 January 2021 Accepted 10 February 2021

\section{References}

1. Khanchi S., Garg V. K. Power factor improvement of induction motor by using capacitors. International Journal of Engineering Trends and Technology (IJETT). 2013. Vol. 4. No. 7. P. 2967-2971.

2. Global Induction Motors Market Forecast 20192027.

3. Sobhani S., Yaghobi H., Samakoosh M. Optimize efficiency and torque in the single-phase induction motor by adjusting the design parameters. In: 2013 12th International Conference on Environment and Electrical Engineering. IEEE. 2013. P. 237-241.

4. Bibik O. V. Formirovaniye energoeffektivnykh rezhimov raboty odnofaznykh kondensatornykh asinkhronnykh dvigateley s periodicheskoy nagruzkoy. Pratsi Instytutu elektrodinamiky Natsionalnoi akademii nauk Ukrainy, 2012. No. 33. P. 45-53.

5. Finkelshtein V., Iegorov O., Petrenko O. The analytic-field method for calculating the squirrel-cage induction motor parameters. Scientific Bulletin of National Mining University (Ukraine), 2020, No. 3. P. 67-72.

6. Belyaev E. F., Tsylev P. N., Shchapova I. N. Symmetrization of an Induction Capacitor Motor by Methods of Mathematical Modeling. Russian Electrical Engineering. 2018. Vol. 89. No. 6. P. 355-359.

7. Finkelshtein V., Iegorov O., Maleev A. Comparison of characteristics of the converter-fed motor at supply from the single-phase network and from the source of the direct current. Elektrotekhnika $i$ elektromekhanika. 2015. No. 4. P. 15-19.

8. Sharma S., Gaur B., Punetha D. Optimization technique to mitigate the losses in single phase induction motor. 2016 International Conference on Advances in Computing, Communication, \& Automation (ICACCA) (Spring), IEEE. 2016. P. 1-4.

9. Iegorov O., Iegorova O., Kundenko M., Milenin A. Single-Phase Induction Motors Winding Parameters Optimization with Maximum Efficiency. 2020 IEEE Problems of Automated Electrodrive. Theory and Practice (PAEP). 21-25 Sept. 2020.

10. Lopukhina Ye. M., Semenchukov G. A. Avtomatizirovannoye proyektirovaniye elektricheskikh mashin maloy moshchnosti. Uchebnoye Posobiye Dlya Elektrotekhnicheskikh Spetsialnostey Vuzov. Moskva: Vysshaya shkola. 2002. 511 p. 
11. Karpe M., et al. Optimization of Single-Phase Induction Motor. In: 2019 IEEE Conference on Energy Conversion (CENCON). 2019. P. 115-120.

12. Finkelshtein V., Iegorov O. Computer program Optimization calculation of single-phase induction motor Certificate of registration of copyright No. 72960, Ukraine, 2017.

Oleksiy Iegorov, Olga Iegorova,

Oleksandr Miroshnyk, Artem Cherniuk

VIENFAZIO ASINCHRONINIO ELEKTROS

VARIKLIO OPTIMALAUS TRANSFORMACIJOS

KOEFICIENTO NUSTATYMAS

EKSPERIMENTINIU IR SKAIČIUOJAMUOJU

BŪDAIS

\section{Santrauka}

Asinchroniniai elektros varikliai suvartoja apie $70 \%$ pasaulio elektros energijos, nes jie naudojami beveik visose besisukančiuose mechanizmuose.

Kiekvienais metais pramoniniams ir buitiniams tikslams pagaminama milijonai naujų elektros variklių. Vienfaziai asinchroniniai varikliai (angl. SPIM - single-phase induction motors) dèl puikių projektinių sprendimų ir žemos kainos yra tobuliausi vienfaziai elektros varikliai. Net ir maži SPIM variklių patobulinimai gali turèti labai didelę ịtaką elektros vartojimui pasaulyje, sumažinti žalingų medžiagų emisiją i aplinką. Straipsnyje aprašoma SPIM apvijų optimizavimo metodika, leidžianti padidinti naudojamo nekintančios talpos kondensatoriaus, skirto fazių poslinkiui, efektyvumą. Metodikos naudingumas patvirtintas atliekant eksperimentus su skirtingomis galiomis ir rotoriaus greičiais.

Raktažodžiai: asinchroninis variklis, apvijos, faze slenkantis kondensatorius, efektyvumas, teigiamos ir atvirkštinès sekos srovès 